\title{
Interactions between Crassostrea virginica larvae and Deepwater Horizon oil: Toxic effects via dietary exposure
}

\author{
Vignier J. ${ }^{1,2,{ }^{*}}$, Rolton A. ${ }^{1,2}$, Soudant Philippe ${ }^{2}$, Chu F.L.E. ${ }^{3}$, Robert Rene ${ }^{4}$, Volety A.K. ${ }^{1,5}$
}

${ }^{1}$ Department of Marine and Ecological Sciences, College of Arts and Sciences, Florida Gulf Coast University, Fort Myers, FL, 33965, USA

${ }^{2}$ Laboratoire des Sciences de l'Environnement Marin (UMR 6539-LEMAR), IUEM-UBO, Technopole Brest Iroise, 29280, Plouzané, France

${ }^{3}$ Virginia Institute of Marine Science (VIMS), College of William and Mary, Department of Aquatic Health Science, Gloucester Point, VA, 23062, USA

${ }^{4}$ Ifremer, Unité Littoral, Centre Bretagne - Zl de la Pointe du Diable - CS 10070, 29280, Plouzané, France

${ }^{5}$ University of North Carolina Wilmington, College of Arts and Sciences, 601 South College Road, Wilmington, NC, 28403-5912, USA

*Corresponding author : J. Vignier, email address : julien.vignier@cawthron.org.nz

\begin{abstract}
:
The Deepwater Horizon (DWH) disaster released crude oil in the Gulf of Mexico for 87 days, overlapping with the reproductive season and recruitment of the oyster Crassostrea virginica. The pelagic larval life stages of $C$. virginica are particularly vulnerable to contaminants such as polycyclic aromatic hydrocarbons (PAHs) and oil droplets. Based on their lipophilic properties, PAHs and oil droplets can adsorb onto phytoplankton and filter-feeding $C$. virginica larvae may be exposed to these contaminants bound to suspended sediment, adsorbed onto algal and other particles, or in solution. This study examined the effects of exposure of $C$. virginica larvae to algae mixed with DWH oil. In a 14day laboratory exposure, 5 day-old $C$. virginica larvae were exposed to Tisochrysis lutea mixed with four concentrations of unfiltered DWH oil (HEWAF) in a static renewal system. Larval growth, feeding capacity, abnormality and mortality were monitored throughout the exposure. Total PAH $(n=50)$ content of the water medium, in which larvae were grown, were quantified by GC/MS-SIM. Oil droplets were observed bound to algae, resulting in particles in the size-range of food ingested by oyster larvae (1$30 \mu \mathrm{m})$. After 14 days of exposure, larval growth and survival were negatively affected at concentrations of tPAH50 as low as $1.6 \mu \mathrm{g} \mathrm{L}^{-1}$. GC/MS-SIM analysis of the exposure medium confirmed that certain PAHs were also adsorbed by $T$. lutea and taken up by oyster larvae via ingestion of oil droplets and/or

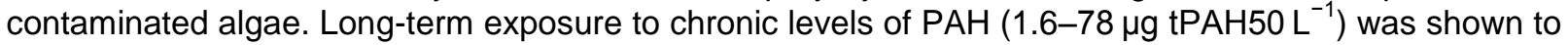
negatively affect larval survival. This study demonstrates that dietary exposure of oyster larvae to DWH oil is a realistic route of crude oil toxicity and may have serious implications on the planktonic community and the food chain.
\end{abstract}




\section{Graphical abstract}

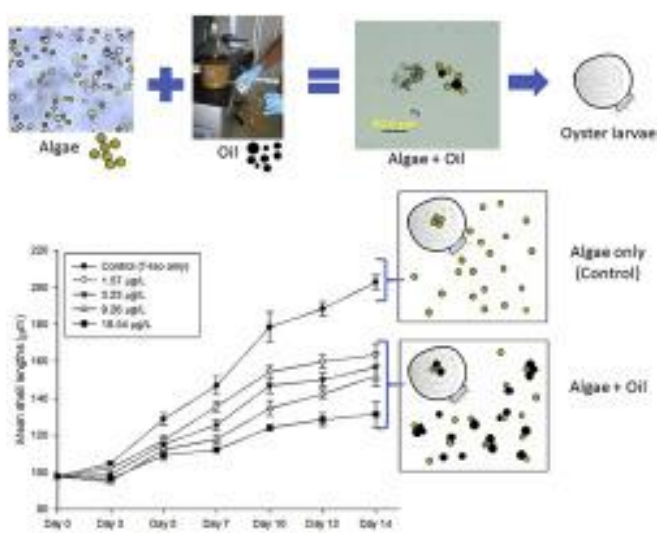

\section{Highlights}

- Oyster larvae were exposed for 14 days to Deepwater Horizon oil via a dietary route. Oil droplets and PAHs were adsorbed to phytoplankton and ingested by oyster larvae. Larval growth and survival were impaired at environmentally realistic levels of $\mathrm{PAH}$. Chronic levels of PAH may have implications on oyster populations and the ecosystem.

Keywords : Deepwater Horizon oil, Droplet, Oyster larvae, Dietary exposure, PAH 


\section{Introduction}

The 2010 explosion of the offshore drilling unit Deepwater Horizon (DWH) generated the largest marine oil spill in United States history, with an estimated 507 million L of crude oil released into the Northern Gulf of Mexico (U.S. District Court, 2015). The resulting deep sea "plume" caused extensive oiling of the pelagic zone and fouling of over $2000 \mathrm{~km}$ of shoreline (Boesch, 2014; Nixon et al, 2015). Crude oil spilled from the Macondo- 1 well from April $20^{\text {th }}$ until July $15^{\text {th }}$ (U.S District Court, 2014), coinciding with the natural spawning season and recruitment of the eastern oyster, Crassostrea virginica, in the Gulf of Mexico (Ingle, 1951; Hayes and Menzel, 1981). Following spawning and fertilization, developing free-swimming C. virginica larvae spend 2 - 3 weeks in the water column, usually floating near the surface, until they settle on a suitable substrate (Bahr and Lanier, 1981). Recent studies have demonstrated the toxic effects of DWH crude oil on the early life stages of $C$. virginica, notably, damage to sperm and oocyte functions causing a reduction in fertilization success (Volety et al., 2016; Vignier et al., 2017), an increase in embryo and larval defects, retardation in larval growth and a decline in settlement success, and ultimately mortalities (Laramore et al., 2014; Vignier et al., 2015, 2016; Langdon et al., 2016; Stefansson et al., 2016; Finch et al., 2016, 2018; Boulais et al., 2018).

Following an oil spill, energy from the wind and waves cause the oil on the surface to break, generating oil droplets in the water column (Delvigne and Sweeney, 1988; Mukherjee and Wrenn, 2009). Larger droplets resurface and coalesce to form thin oil films, while plumes of smaller dispersed oil droplets (1-100 $\mu \mathrm{m}$ in diameter), which have a much lower resurfacing velocity, passively drift in subsurface waters (Lichtenthaler and Daling, 1985; Lewis and Daling, 2001). These oil droplets are similar in size to the microalgae within the food size spectra available to zooplankton including filter-feeding organisms such as oyster larvae (1 50 m: Baldwin and Newell, 1991, 1995; Robert et al., 2004; Ponis et al., 2006;) and there is evidence of ingestion of oil droplets by some zooplankton species (Hansen et al., 2012; Lee et al., 2012; Almeda et al., 2013, 2014).

Polycyclic aromatic hydrocarbons (PAHs) are the best indicator of the potential toxicity of spilled crude oil to water-column organisms (Anderson, 1977; Neff and Stubblefield, 1995). The water solubility and volatility of PAHs depends on their molecular weight (Porte and Albaigés, 1994). Lower molecular weight (LMW) compounds are preferentially dissolved and heavier molecular weight (HMW) PAHs are mainly found attached to particulate organic 
matter, sediment, detritus and microalgae (Lee et al., 1978; Rubinstein et al., 1984; Baumard et al., 1999). PAHs have a high affinity for biological compartments with high lipid content (Neff, 1979; Spacie et al., 1995). Microalgae are living photosynthetic particles rich in lipids to which lipophilic PAHs can adsorb (Herbes et al., 1977; Lee et al., 1978; Widdows et al., 1982; Meador et al., 1995). This adsorption of organic pollutants to suspended particles in the water column is an essential process influencing the bioavailability and toxicity of hydrophobic pollutants (Lyman, 1995; Chu et al., 2003). The uptake of pollutants from water, sediment, and food sources are three routes by which filter-feeding animals, including oysters, can be exposed to PAHs and in the natural environment, these exposure routes occur simultaneously (Spacie et al., 1995). Consequently, PAHs can enter the food web and be potentially transferred to higher trophic levels as these food particles are ingested and accumulated by filter-feeding organisms (Okay et al., 2000; Wolfe et al., 1998; 2000).

As such, oyster larvae may take up petroleum hydrocarbons directly, through passive uptake or absorption of the dissolved fraction of oil across biological membranes (Kayal and Connell, 1990), by ingestion of oil droplets, or through the ingestion of contaminated phytoplankton (Okay et al., 2000; Croxton et al., 2012). A previous study, exposing various stages of oyster larvae to DWH oil and dispersant, revealed that oil droplets were present in the body cavity of oysters, indicating that larvae were able to directly filter oil droplets (Vignier et al., 2016).

The goal of the present study was to evaluate the lethal and sublethal effects of DWH oil on Crassostrea virginica larvae via dietary exposure.

\section{Material and Methods}

\subsection{Preparation of oil solution}

Surface oil (Slick A, sample CTC02404-02) was collected near the source during the Deepwater Horizon oil spill on 29 July 2010 from a barge holding mixed oil offloaded from several skimmer vessels and was provided under chain of custody by the DWH trustees.

The high energy water accommodated fraction (HEWAF) exposure solutions were prepared following a standardized procedure detailed in Vignier et al. (2016). The HEWAF method 
was adopted to artificially recreate the actions of currents, winds, and waves on oil slicks. The HEWAF stock solution (nominal oil loading rate of $2 \mathrm{~g}$ oil L $\mathrm{L}^{-1}$ ) was not filtered, and thus consisted of both particulate oil and dissolved PAHs.

\subsection{Experimental oyster and microalgae}

Adult Crassostrea virginica (average weight of $85 \mathrm{~g} \pm 12$ ) were collected in October 2012, from natural beds in Estero Bay, Florida. Estero Bay is an aquatic buffer preserve which has extensive healthy oyster reefs. Oysters were acclimated and conditioned in a flow-through system supplied with coarsely filtered $(30 \mu \mathrm{m})$ seawater adjusted at $23^{\circ} \mathrm{C} \pm 1$ and at ambient salinity of 20-30, and fed a mixture of cultured phytoplankton (Tetraselmis chui, Chaetoceros muelleri and Tisochrysis lutea) according to Utting and Millican (1997). The microalgae, T. chui, C. muelleri and T. lutea, were grown in f/2 culture medium (Guillard, 1975) prepared with previously autoclaved 1- $\mu \mathrm{m}$-filtered and UV-treated seawater (FSW), and held in $10 \mathrm{~L}$ carboys at $22-23^{\circ} \mathrm{C}$ and a salinity of $30-32$ on a $12: 12$ light: dark cycle with cool-white fluorescent lights and appropriate aeration.

Mature oysters were induced to spawn in the hatchery by thermal stimulation. Gamete collection, fertilization and early larval rearing were carried out following methods previously described in Vignier et al. (2016).

\subsection{Dietary exposure}

\subsubsection{Preparation of contaminated algae}

Tisochrysis lutea (CCMP 1324; equivalent spherical diameter ESD $\approx 5 \mu \mathrm{m}$ ) was used as the contaminant vector to feed oyster larvae for the duration of the exposure. Each exposure concentration was prepared by volumetrically adding stock solution of DWH oil prepared as HEWAF (2,000 ppm nominal oil load) to the algal suspension in a $400 \mathrm{~mL}$ glass beaker, to achieve a final algal concentration of $4.5 \times 10^{6}$ cells $\mathrm{mL}^{-1}$ and final oil nominal concentrations of $31.25,62.5,125$ and $250 \mathrm{ppm}$. Experimental nominal concentrations chosen for this study were based upon results from a previous "range-finding" experiment in which no significant effects on i) larval survival and ii) microalgae viability were observed. Each beaker, containing $300 \mathrm{~mL}$ of different nominal concentrations of algae-oil mixture, was gently 
stirred $(250 \mathrm{rpm})$ using a stir bar for $6 \mathrm{~h}$, allowing the oil to impregnate the algae, and left in the dark, covered with parafilm.

\subsubsection{Oil droplet size distribution}

A stock solution of HEWAF (2,000 ppm) was examined on a glass slide using an Olympus IX73 inverted microscope equipped with an Olympus DP73 camera. Oil droplet diameters were randomly measured and counted using an image analysis software (CellSens), and a size distribution was determined (Supplementary file S2).

\subsubsection{Flow-cytometry analysis}

To determine the different populations of particles (oil droplets, algae and algae/oil) as well as their relative sizes, each exposure oil and algae suspension was analyzed by flow cytometry using a Beckman-Coulter, Cytomics FC 500, and side scatter (SSC), forward scatter (FSC) and orange fluorescence (FL2) were measured. Samples were acquired during $30 \mathrm{~s}$ at a fixed flow rate $\left(0.59 \mu \mathrm{L} \mathrm{s}^{-1}\right)$ and the proportion of algae and oil droplets, alone or combined, were determined by counting the number of events (particles) in $30 \mathrm{~s}$.

\subsubsection{Larval exposure protocol}

Late veliger larvae ( 5 day-old, mean initial length $=97.7 \mu \mathrm{m} \pm 0.6, \mathrm{n}=103$ ) were collected from the hatchery on a $55 \mu \mathrm{m}$ sieve. Larvae were stocked at about $13 \mathrm{~mL}^{-1}$ (about 20,000 per jar) and exposed to oil-contaminated algae (T. lutea) for 14 days, in $1500 \mathrm{~mL}$ sterile glass jars, using a static-renewal system. To prevent the loss of some PAHs by evaporation or attachment to surfaces, which would reduce the potential toxicity of oil after several days, exposure media were changed every 2 days. DWH oil stock was prepared as high energy (HEWAF) method (see 2.1) and mixed with the algae for $6 \mathrm{~h}$ (section 2.3.1). Algae and oil mixtures were added to each exposure vessel/jar at the start of the exposure, and every other day after each water renewal, at a feeding regime of 150,000 cells $\mathrm{mL}^{-1}$ of $T$. lutea (total of $225 \times 10^{6}$ cells $T$. lutea per jar).

Four exposure concentrations of oil-contaminated algae with 4 replicates per treatment were tested. The final concentrations of algae-oil mixture, expressed in $\mathrm{PAH}(\mathrm{n}=50)$ to which 
oyster larvae were exposed over the duration of the experiment were 1.57, 3.23, 9.26, and $18.54 \mu \mathrm{g}$ tPAH50 $\mathrm{L}^{-1}$. Control treatments were fed uncontaminated algae. Gentle aeration was provided to stimulate feeding and maintain sufficient dissolved oxygen (D.O). Water was renewed every other day by pouring the entire contents (water, larvae, remaining algae and oil) through a $55 \mu \mathrm{m}$ sieve, separating the larvae from the exposure media (including algal and oil particles). Retained larvae were then gently washed with FSW and re-suspended into a cleaned exposure jar containing fresh FSW. After the water renewal, about $50 \mathrm{~mL}$ of algae/oil mixtures (equivalent to $3.33 \%$ of the total volume of larval culture) were added per jar.

\subsubsection{Subsampling and measurements}

On the first day of exposure and before each renewal, sub-samples of $10 \mathrm{~mL}$ were taken from all exposure jars and fixed with $10 \%$ buffered formalin for microscope examination of abnormality, shell length and viability of the larvae. Abnormalities included abnormally extended or necrotic velum. To assess growth, shell length was measured every 2 days (minimum of 200 individuals per treatment) using an inverted microscope Olympus IX73 equipped with a camera Olympus DP73 and the CellSens Software. In addition, the percentage of larvae with the presence of food in the stomach were assessed for each sample. At the end of the exposure (day 14), after taking a $10 \mathrm{~mL}$ sub-sample for examination of abnormality and shell length, the remaining larvae in each replicate of each treatment were collected on a $55 \mu \mathrm{m}$ sieve, rinsed and re-suspended in $30 \mathrm{~mL}$ of FSW. After thorough mixing, 3 subsamples of $300 \mu \mathrm{L}$ were taken from the concentrate $(30 \mathrm{~mL})$ of each replicate and observed under magnification to count live and dead larvae (translucent shells or opened valves). Final survival was then determined by dividing the number of survivors by the initial number of larvae stocked.

\subsection{Water quality and PAH analysis}

Throughout the exposure period, temperature and dissolved oxygen (D.O) were monitored daily by means of a Pro ODO optic probe (YSI), while salinity and pH were measured daily using a refractometer (Pentair Aquatic Eco-systems Inc., Apopka, FL, USA) and a "Pinpoint" pH monitor (American Marine Inc., Ridgefield, CT, USA) respectively. Total ammonia was 
quantified at the start, before each water change and at the end of the exposure experiment, using a Seal Analytical Auto Analyzer 3 and the G-171-96 method.

Analytical chemistry was performed by ALS Environment (Kelso, WA, USA). Polycyclic aromatic hydrocarbons, parents and alkyl homologues, were measured by gas chromatography with low resolution mass spectrometry using selected ion monitoring (GC/MS-SIM) and a sum of 50 PAHs were determined (Supplementary file S1). The analytical procedure was based on EPA Method 8270D with the GC and MS operating conditions optimized for separation and sensitivity of the targeted analytes. Two distinct sets of water samples were collected throughout the 14 days exposure. The first set was taken at test initiation (day 0 ), less than $1 \mathrm{~h}$ after feeding with algae, from an additional ' 5 th, replicate from each treatment group which was prepared without larvae specifically for water sampling. The second set consisted of effluent water samples (containing algae and oil) taken during the first water renewal from each treatment group, after sieving of the larvae.

\subsection{Statistical analyses}

Percentage data were arcsine-square root transformed prior to statistical analysis. Using SPSS $22.0^{\circledR}$ statistical package, the assumption of normality and homoscedasticity amongst treatments were verified by a Shapiro-Wilk test and a Levene's test respectively. Analyses of variance (ANOVA) were then conducted on data to obtain lowest effective concentration (LOEC). Whenever significant differences among groups were found (ANOVA: $p<0.05$ ), a Tukey post-hoc test was performed. When data did not meet homoscedasticity requirements, Dunnett's T3 post-hoc tests were used.

In addition to ANOVAs, dose-response curves were fitted using log-logistic models with the drc package in R version 3.1.1 (2014) (Ritz and Streibig, 2005; Ritz, 2010). For binomial response variables (abnormality, mortality), a 3-parameter log-logistic model was fitted, while for growth, a 4-parameter log-logistic model was fitted. Median-effects and lethal concentrations (ECX/LCx) were estimated from these fitted models. All results are presented with $95 \%$ confidence intervals (CI). 


\section{Results}

\subsection{Water quality and PAH content}

Throughout the 2 week exposure, temperature and salinity were $25.5^{\circ} \mathrm{C} \pm 0.7$ and $22.2 \pm 0.7$ respectively. Dissolved oxygen (D.O.) and $\mathrm{pH}$ averaged $7.15 \mathrm{mg} \mathrm{L}^{-1} \pm 0.13$ and $7.74 \pm 0.34$ respectively. Total ammonia concentration remained below $0.5 \mathrm{mg} \mathrm{L}^{-1}$, levels causing no deleterious effects to oyster larvae (i.e. NOEC $\approx 4 \mathrm{mg} \mathrm{L}^{-1}$ ) according to Losso et al. (2007). Chemical composition of DWH crude oil (S1A) corresponded closely with that of the HEWAF stock solution (S1B).

\subsection{Droplet size distribution and flow-cytometry analysis}

Analysis of unfiltered HEWAF solution (oil only) indicated that oil droplets ranged from less than $1 \mu \mathrm{m}$ to $22 \mu \mathrm{m}$ in size, with the majority $(\approx 90 \%)$ of droplets in the $\leq 1$ to $5 \mu \mathrm{m}$ size range (S2). Size of these oil particles (mean diameter: $1.85 \mu \mathrm{m} \pm 0.62$ ) was similar to that of small diatoms or flagellates, such as $T$. lutea $(\mathrm{ESD}=5 \mu \mathrm{m})$, on which oyster larvae feed (Robert et al., 2004).

Flow-cytometric analysis of solutions of $T$. lutea mixed with increasing HEWAF revealed three distinct populations of particles with different fluorescence but with a similar range of relative size: T. lutea, oil droplets and T. lutea/oil droplets (Fig. 1A). Further analysis using flow-cytometry showed that the number of oil droplets associated/aggregated with algal cells increased with increasing concentrations of HEWAF, up to about $15 \%$ for the highest HEWAF treatment, demonstrating that oil could adsorb to phytoplankton (Fig. 1B).
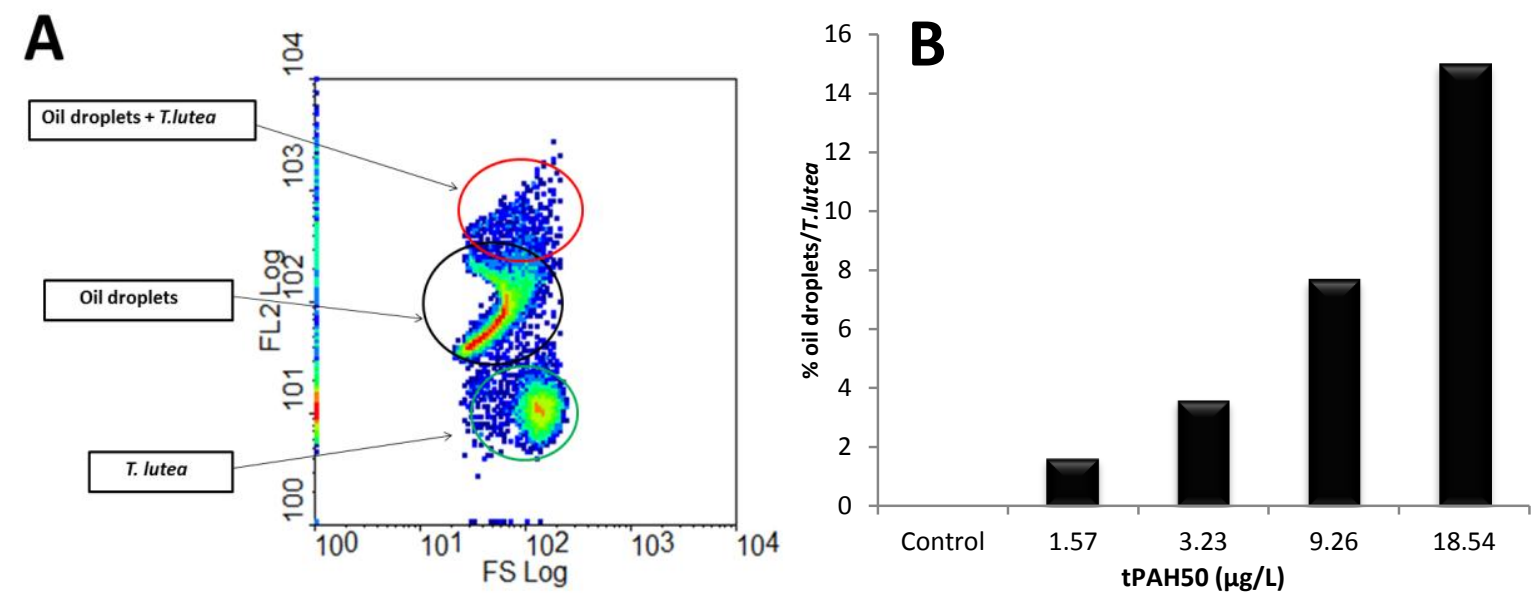
Figure 1: (A) Cytogram showing the different populations of particles separated based on relative size (FSC) and orange fluorescence (FL2). (B) Percentages of oil droplets associated with T. lutea cells after $6 \mathrm{~h}$ mixing with increasing concentrations of HEWAF (in $\mu \mathrm{g}$ tPAH50 $\mathrm{L}^{-1}$ ).

\subsection{PAHs content in exposure/culture media (oil-contaminated algae)}

An increase of tPAH50 in the exposure medium (algae + water +oil) was recorded with increasing doses of oil added to the algae (Fig. 2). In addition, GC/MS-SIM analysis showed a decline of tPAH50 (about 4 times) measured in the exposure medium through time (Fig. 2).

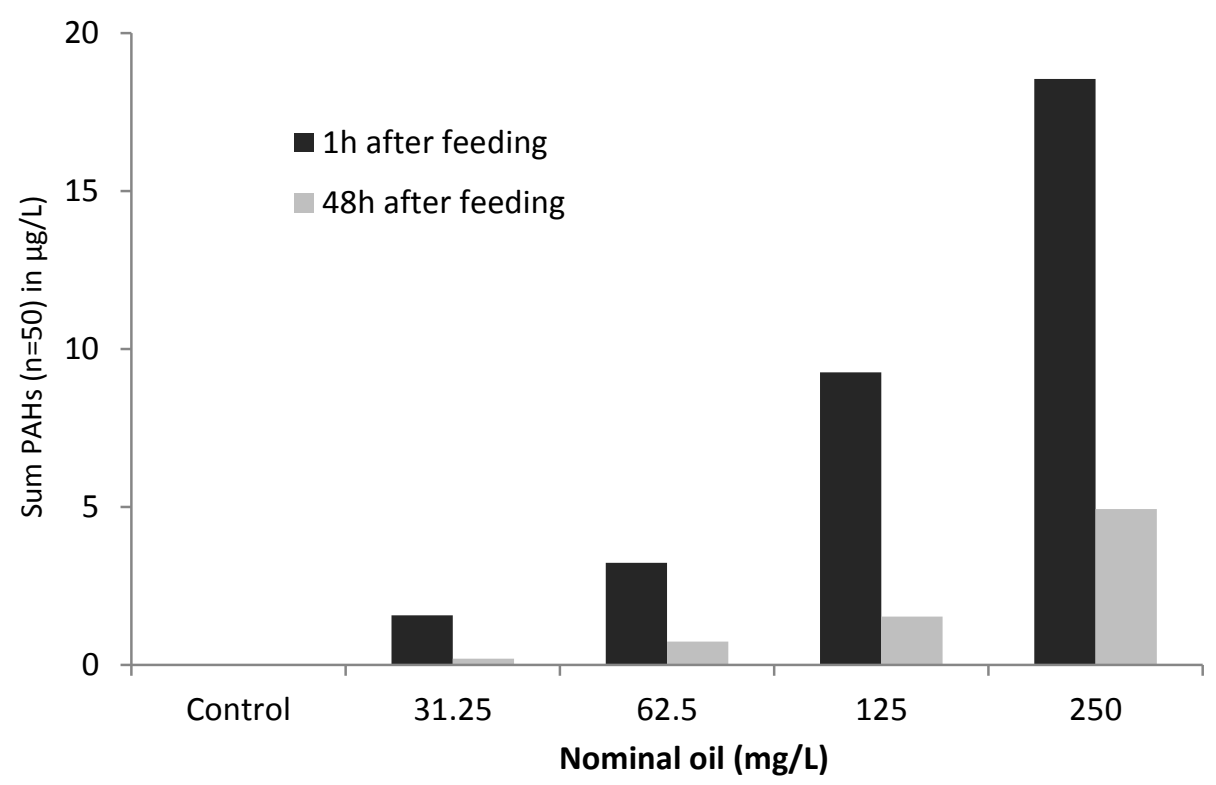

Figure 2: PAH content of the exposure medium (water + algae + oil), $1 \mathrm{~h}$ after feeding with increasing concentrations of oil-contaminated $T$. lutea (black), and after $48 \mathrm{~h}$ of exposure just before water renewal (grey), expressed in $\mathrm{mg} \mathrm{L}^{-1}$. Sum of 50 PAHs (tPAH50), quantified using GC MS-SIM, is expressed in $\mu \mathrm{g} \mathrm{L}^{-1}$. Samples were not filtered (i.e. contain algae and oil). See Fig 3 for PAH profiles at the highest exposure dose $1 \mathrm{~h}$ after feeding and after $48 \mathrm{~h}$ of exposure. 


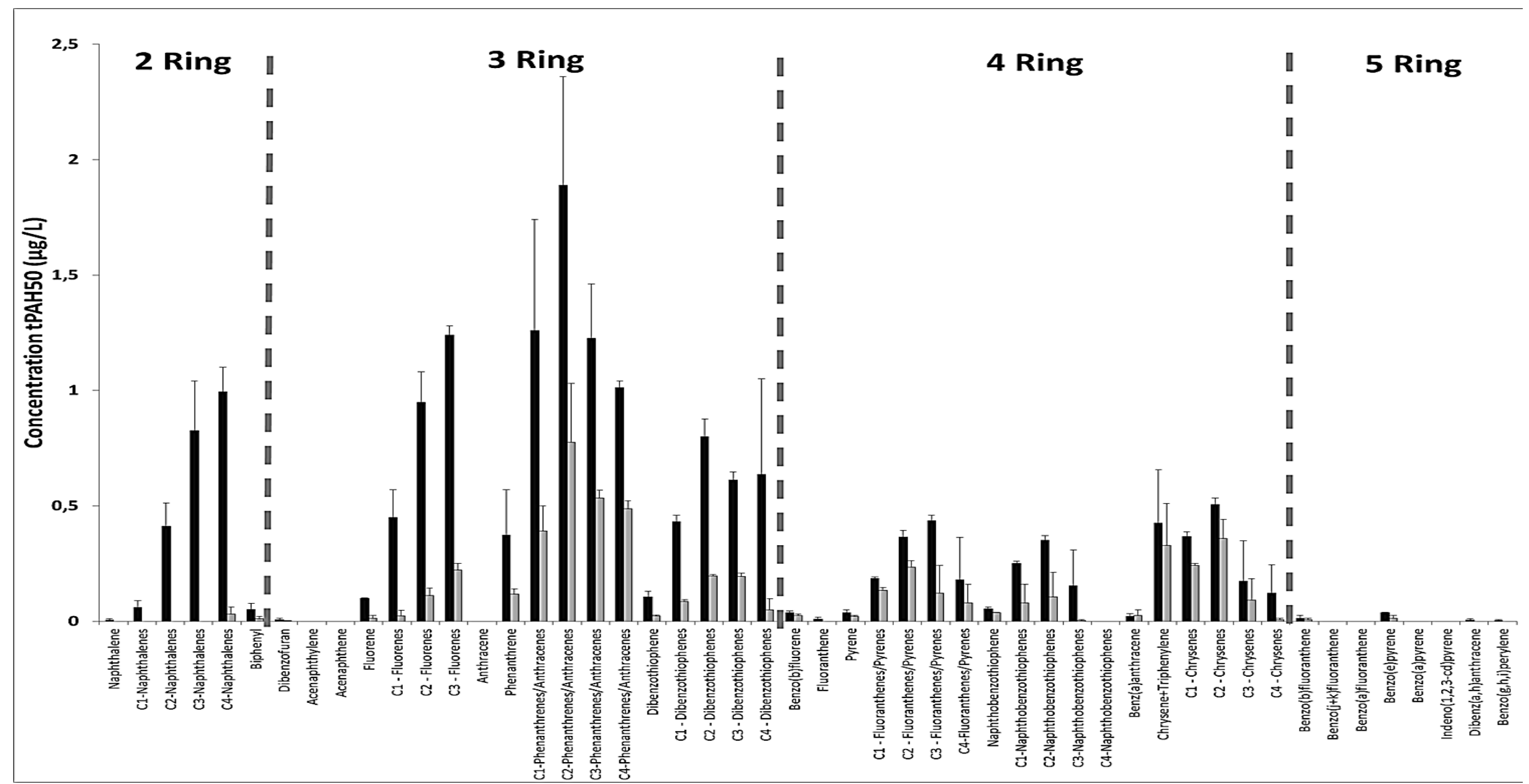

Figure 3: Concentrations for $50 \mathrm{PAH}$ analytes in the culture medium $1 \mathrm{~h}$ (black) and $48 \mathrm{~h}$ (grey) after feeding with the highest dose of oil-contaminated algae as determined by GC-MS/SIM. Concentration of individual PAH is expressed in $\mu \mathrm{g} \mathrm{L}^{-1}( \pm \mathrm{SD})$. N0-4: Napthalene; B: Biphenyl; DF: Dibenzofuran; AY: Acenaphtylene; AE: Acenaphtene; F03: Fluorene; A0: Anthracene; PA0-4: Phenanthrene; DBT0-4: Dibenzothiophene; BF:Benzo(b)fluorine; FLO: Fluoranthene; PY0: Pyrene; FP1-4: Fluoranthene/Pyrene; NBT0-4: Naphtobenzothiophene; BAO: Benz(a)anthracene; C0-4: Chrysene; BBF: Benzo(b)fluoranthene; BJKF: Benzo(j+k)fluoranthene; BAF: Benzo(a)fluoranthene; BEP: Benzo(e)pyrene; BAP: Benzo(a)pyrene; IND: Indeno(1,2,3)pyrene; DA: Dibenz(a,h)anthracene; GHI: Benzo(g,h,i)perylene. Parent compound is indicated by a 0 (e.g. N0), while numbers of additional carbons for alkylated homologs are indicated as N1, N2, etc. Samples were not filtered. 
The PAH profile of the exposure medium $1 \mathrm{~h}$ after the highest dose of oil-contaminated algae was fed to the larvae, and $48 \mathrm{~h}$ later before exposure medium was renewed is shown in figure 3. At the start of the exposure (1h), PAH peaks of the exposure solution (oil-contaminated algae) consisted of mostly bi-aromatic (Naphtalene, Fluorene), tri-aromatic (Anthracene/Phenanthrene, Dibenzothiophene) and to a lesser extent tetra-aromatic hydrocarbon (Pyrene, Naphtobenzothiophene, Chrysene) (Fig. 3). Before the water change and the renewing of exposure solution, the PAH profile of the medium in which larvae were exposed, comprised tri- and tetra-aromatic compounds mainly, and bi- and penta-aromatic at low levels (Fig. 3).

\subsection{Effects on growth, survival and feeding regime}

The daily growth of larvae, continuously exposed to oil-contaminated algae, was negatively affected in a dose-dependent manner (Fig. 4A). In the control treatment, larvae fed only $T$. lutea exhibited a daily growth of $7.5 \mu \mathrm{m}( \pm 0.29)$ (Fig. 4A), with mean shell length increasing from $97.7 \mu \mathrm{m}( \pm 0.6)$ to $202.6 \mu \mathrm{m}( \pm 3.7)$ after 14 days (Fig. 4B). Contrastingly, the exposure solution containing the lowest dose of oil-contaminated algae (equivalent to $1.57 \mu \mathrm{g} \mathrm{L}^{-1}$ of tPAH50) affected growth significantly ( $p \leq 0.01$, Fig. 4A). At intermediate concentrations of PAHs ranging from 3.23 to $9.25 \mu \mathrm{g} \mathrm{L}^{-1}$, growth inhibition reached about $50 \%$ after 14 days (Fig. 4A). At the highest concentration tested, larvae were affected the most $(p \leq 0.001$, Fig. $4 \mathrm{~A}$ ), with a cumulative growth of $\approx 30 \mu \mathrm{m}$ in 14 days; the mean size at the end of the experiment was $131.4 \mu \mathrm{m}( \pm 6.8)$ (Fig. 4B). 


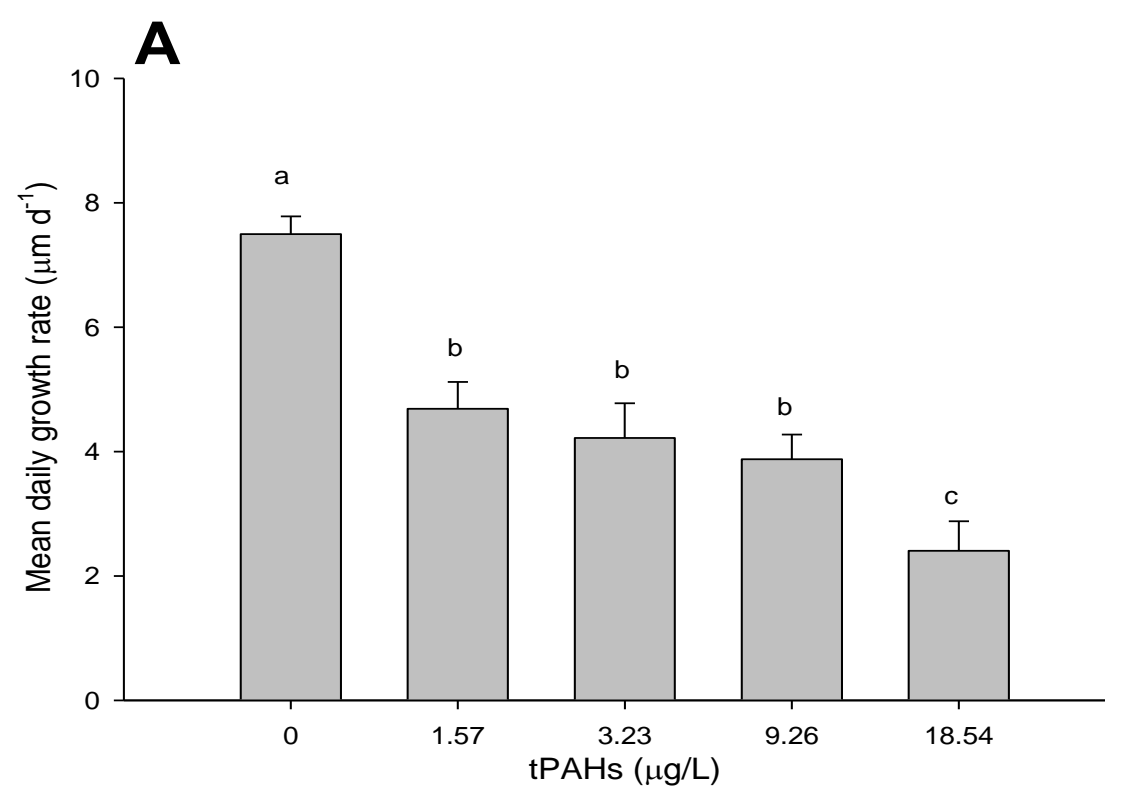

B

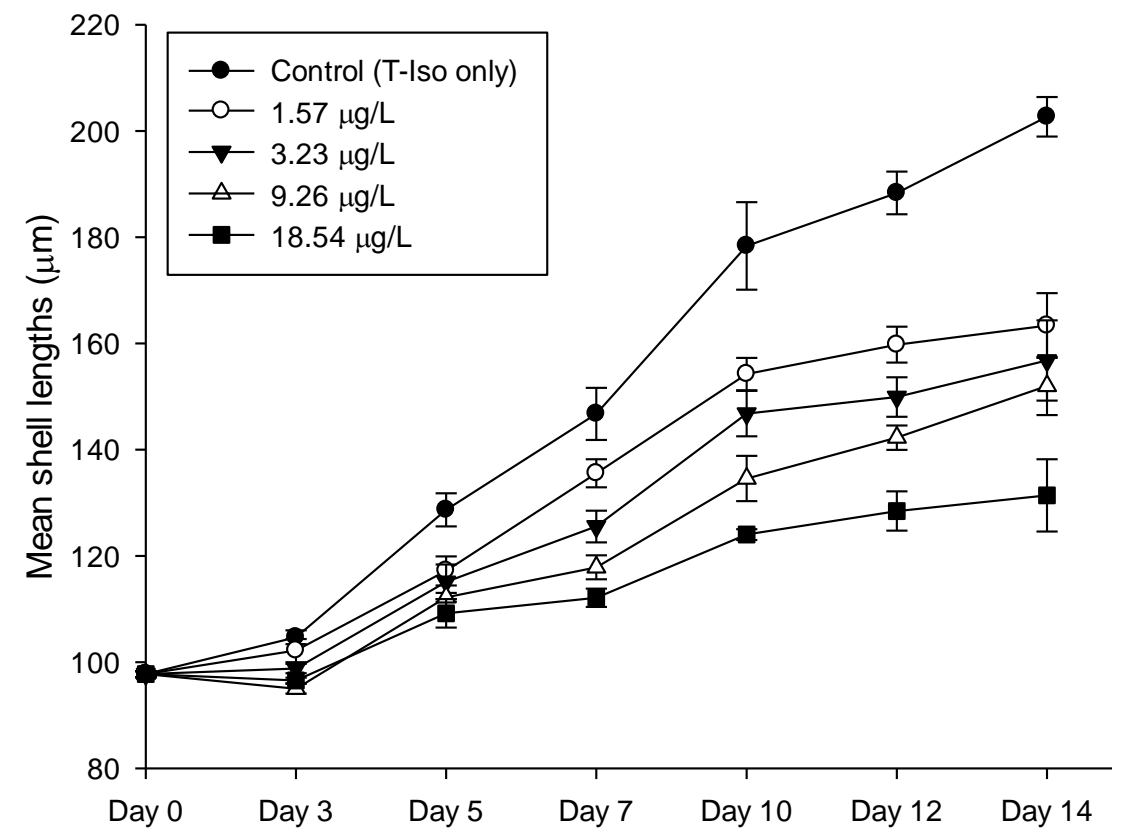

Figure 4: (A) Growth of oyster larvae, expressed in daily growth rate $\left(\mu \mathrm{m} \mathrm{d}^{-1}\right)$. Different letters denote statistically significant differences between condition (ANOVA, $\mathrm{p}=0.05$ ). (B) Evolution of shell length $(\mu \mathrm{m})$ of larvae fed Tisochrysis lutea mixed with increasing concentrations of oil/PAH (expressed in $\mu \mathrm{g}$ of $\mathrm{tPAH} 50 \mathrm{~L}^{-1}$ ) for 14 days. Data are presented as mean shell length $\pm \mathrm{SD}$.

Larval survival at the end of the exposure (day 14) was negatively impacted in a dosedependent way, with significant deleterious effects of oil-contaminated algae at concentrations as low as $3.23 \mu \mathrm{g}$ tPAH50 L ${ }^{-1}$ (ANOVA: $p=0.019$, Fig. 5). However, survival remained above $67 \%$ (in the highest treatment) in all treatments. 


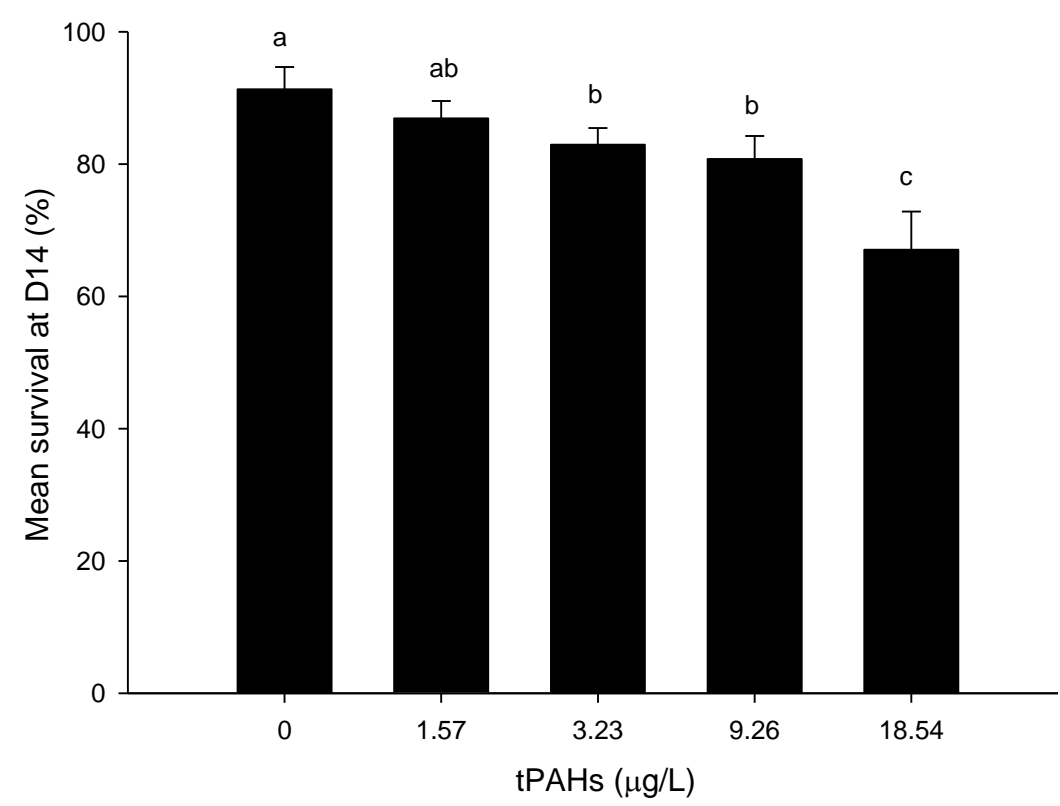

Figure 5: Survival of oyster larvae exposed for 14 days to Tisochrysis lutea mixed with increasing concentrations of oil, expressed in $\mu \mathrm{g}$ of tPAH50 $\mathrm{L}^{-1}$. Data are presented as mean percentages \pm SD. Different letters denote statistically significant differences between condition (ANOVA, $\mathrm{p}=0.05$ ). Final survival was calculated using the number of live larvae observed at the end of the exposure, divided by the total number initially stocked.

The concentration of PAHs causing $50 \%$ of mortality after 14 days of exposure $\left(\mathrm{LC}^{2} \mathrm{O}_{336 \mathrm{~h}}\right)$ to oil-contaminated algae was estimated at $78 \mu \mathrm{g}$ tPAH50 L $\mathrm{L}^{-1}$ (Table 1). Abnormalities were observed in exposed larvae, comprising abnormally extended or necrotic velum. Concentrations of oil-contaminated T. lutea equivalent to $27.2 \mu \mathrm{g}$ tPAH50 $\mathrm{L}^{-1}$ induced $50 \%$ of abnormal larvae $\left(\mathrm{EC} \mathrm{0}_{336 \mathrm{~h}}\right)($ Table 1).

Table 1: Effective (ECx) and lethal concentrations (LCx) of oil-contaminated T. lutea causing 50\% abnormality, growth inhibition and mortality after $336 \mathrm{~h}$ of exposure, calculated using the $d r c$ and bbmle packages in R. Lowest concentration having an effect (LOEC) determined from Fig. 5 (ANOVA). ECx, LOEC and LCx values are expressed in $\mu \mathrm{g}$ tPAH50 $\mathrm{L}^{-1}( \pm 95 \%$ C.I).

\begin{tabular}{cccc}
\hline Abnormality & Growth Inhibition & \multicolumn{2}{c}{ Mortality } \\
EC50 $_{336 \mathrm{~h}}$ & EC50 $336 \mathrm{~h}$ & LOEC $_{336 \mathrm{~h}}$ & LC50 $_{336 \mathrm{~h}}$ \\
\hline $\mathbf{2 7 . 2}$ & $\mathbf{6 . 8}$ & $\mathbf{3 . 2}$ & $\mathbf{7 8}$ \\
$(3.1-51.3)$ & $(6.5-7.1)$ & & $(52.8-132)$ \\
\hline
\end{tabular}

Gut content of the larvae (percentage of larvae with algae present in stomach) was quantified at the start of the experiment and at various times during the exposure. No trend was observed between the control treatments and the exposed treatments (data not shown). Association of oil droplets in the body cavity of larvae were frequently observed. 


\section{Discussion}

We found that, in addition to the dissolved fraction, the toxicity of crude oil can also be attributed to the particulate fraction, and that dietary exposure is a possible and realistic route of contamination of oyster larvae. Negative effects of exposing umbo larvae of $C$. virginica to mechanically dispersed oil (HEWAF) for $96 \mathrm{~h}$ were previously demonstrated by Vignier et al. (2016). Following that acute exposure, droplet-associated oil and PAHs were shown to induce severe effects on growth, due in part to the mechanical action but also ingestion of these droplets (Vignier et al., 2016). In the present study, measurements of the particulate form of DWH oil prepared using the HEWAF method indicated that oil droplet size ranged from less than $1 \mu \mathrm{m}$ to $22 \mu \mathrm{m}$, with the majority between less than $1 \mu \mathrm{m}$ and $5 \mu \mathrm{m}$, a result in agreement with other studies ( $\mathrm{Li}$ and Garret, 1998; Hansen et al., 2012; Lee et al., 2012; Forth et al., 2017; Sandoval et al., 2017). Analysis of oil-contaminated algae using flow cytometry showed that a significant fraction (approximately 1/6) of particles present in the mixture were oil droplets aggregated with algae (Fig. 1B) demonstrating that highly lipophilic oil droplets can bind to the unicellular flagellate T. lutea. In addition, the oil droplet-associated algal cells had a similar relative size spectrum as algal cells alone (i.e. 5$15 \mu \mathrm{m})$. This result suggests that droplet-associated algae as well as oil droplets were well within the size range of particles ingested by $C$. virginica larvae, i.e. between 0.2 and $30 \mu \mathrm{m}$ (Baldwin and Newell, 1991; 1995; Robert et al., 2004; Ponis et al., 2006). Indeed, a high occurrence of larvae with the presence of oil droplets in the gut and the stomach were observed at the highest dose of oil-contaminated algae, confirming that larvae were feeding directly on oil droplets, associated or not, to algae. Consequently, direct ingestion of particulate oil might have affected vital functions of the larvae such as swimming abilities or assimilation of food, as illustrated by abnormal and impaired velum, and ultimately affected larval growth. Lee et al. (2012) observed the same phenomenon with Dolioletta gegenbauri, a species of pelagic tunicate abundant in the Gulf of Mexico, which ingested mechanicallydispersed oil droplets, ranging between 1 and $30 \mu \mathrm{m}$. Hansen et al. (2012) demonstrated that the copepod, Calanus finmarchicus, could also feed on oil droplets $(10-15 \mu \mathrm{m})$ which consequently decreased its filtration rates and survival.

A reduction in the measured $\mathrm{PAH} 50$ in the PAH profiles of the exposure media in which larvae were grown (oil, algae, water) was recorded between $\mathrm{T}_{1 \mathrm{~h}}$ and $\mathrm{T}_{48 \mathrm{~h}}$. Exposures were conducted using FSW treated with antibiotic and under artificial lights (no UV radiation) in 
the present study, which would result in negligible biodegradation and photo-oxidation. Such $\mathrm{PAH}$ depletion may be due to evaporation or direct ingestion. The PAH content of the exposure media (Figs. 2 and 3) showed that some bi-aromatic compounds (e.g. Naphtalene) were absent after $48 \mathrm{~h}$, suggesting either a loss by evaporation (Atlas, 1995; Daling et al., 2014 ) and/or most likely an ingestion of oil droplets and/or contaminated algae by larvae.

Analytical chemistry of the exposure medium at $\mathrm{T}_{1 \mathrm{~h}}$, corresponding to oil droplets and the oil/algae mixture, showed that naphthalene and fluorene (parent and alkyl-homologues) and tri-aromatic compounds (Phen, Anth, DBT) constituted the major classes of PAHs and to a lesser extent tetra-aromatic compound (Pyr, NBT, Chry) (Fig. 3). The partitioning of petroleum hydrocarbons between dissolved and particulate phases in waters has been commonly reported as a result of a significant adsorption of PAHs on particulate materials (Herbes, 1977; Lee et al., 1978; Fernandes et al., 1997; Geffard et al., 2003). Due to their hydrophobicity $\left(\mathrm{K}_{\mathrm{ow}}\right.$ ), heavy molecular weight (HMW), hydrocarbons (3 to 6 rings) are preferentially adsorbed onto particles such as lipid-rich microalgae (Lyman, 1995; Baumard et al., 1999; Cerezo et al., 2017). Wolfe et al. (1998) reported an uptake of naphthalene and phenanthrene by Isochrysis galbana (T-Iso) following exposure to WAF crude oil. Similarly, Geffard et al. (2002) demonstrated that I. galbana, previously grown with PAH-contaminated elutriate, accumulated soluble PAH (2 to 4 rings) as a function of their content in the exposure medium. More recently, Cerezo et al. (2017) showed that anthracene and pyrene could be adsorbed to cell surfaces of the phytoplankton species, Tetraselmis suecica. In a similar way, besides droplet-associated PAHs that can bind/adhere to algal cells, soluble PAHs (2-4 rings) may have also been adsorbed by T. lutea.

The relative decline over time of tri- and tetra-aromatic compounds (and possibly biaromatic) observed in the present study (Figs. 2 and 3) suggests that PAHs associated to algal particles were ingested by oyster larvae. Several authors found that PAH could be ingested and accumulated by adult and larval bivalves using a dietary mode of exposure (Widdows et al., 1982; Okay et al., 2000; Geffard et al., 2002; Croxton et al., 2012). The negative effects observed on growth and survival after 14 days of dietary exposure were likely related to the ingestion of these toxic PAHs (Napht, Fluo, Phen, DBT, Pyr, and NBT) by larvae.

The present work also revealed that chronic dietary exposure of oyster larvae to low doses of DWH oil associated-PAHs adversely affects their development. This finding is of great importance as it demonstrates that long-term exposure of oyster larvae to chronic levels of PAH can affect growth, survival and ultimately oyster recruitment. Oil-contaminated algae, 
as low as $1.6 \mu \mathrm{g}$ tPAH50 $\mathrm{L}^{-1}$, significantly slowed larval growth, and $6.8 \mu \mathrm{g}$ tPAH50 L ${ }^{-1}$ completely inhibited growth in 50\% of the animals tested after 14 days of exposure. These results are in agreement with Geffard et al. (2002), who found that larval growth of Crassostrea gigas was impeded after being fed with Isochrysis galbana cultured in the presence of PAH-polluted sediment, at realistic environmental levels. A lengthening of the time spent as a pelagic larva can augment the risk of larval mortality by predation, disease or dispersion (Davis and Hidu, 1969; Calabrese et al., 1973; Beiras and His, 1994), ultimately affecting larval metamorphosis and causing significant decline in spat recruitment. Drinnan and Stallworthy (1979) calculated that a 5 day delay to metamorphosis and settlement could cause a $63 \%$ decline in spat for $C$. virginica, resulting in a major impact on the population. Such reduced growth rates would compromise the ability of juvenile spat to compete for space and reduce their likelihood of successful recruitment to adult population.

Median lethal concentration (LC50) after 14 days reached $78 \mu \mathrm{g}$ tPAH50 L ${ }^{-1}$, with the lowest dose inducing significant mortality attaining $3.2 \mu \mathrm{g}$ tPAH50 $\mathrm{L}^{-1}$. In a field study monitoring waters around the UK, Law et al. (1997) reported chronic concentrations of tPAHs $(n=15)$ ranging from below detection to $10.7 \mu \mathrm{g} \mathrm{L}^{-1}$ in many coastal and estuarine samples. Following an oil spill, concentrations of total PAHs can frequently range from 1 to $150 \mu \mathrm{g} \mathrm{L} \mathrm{L}^{-1}$ (Neff and Stubblefield, 1995). Indeed, concentrations of total PAHs ( $\mathrm{n}=50)$ in water samples collected during the DWH oil spill were reported from below detection limit in distant waters to $189 \mathrm{\mu g} \mathrm{L}^{-1}$ near the well head (Diercks et al., 2010; Wade et al., 2011). Allan et al (2012) reported value of $0.17 \mu \mathrm{g}$ tPAH33 $\mathrm{L}^{-1}$ in coastal waters (Grand Isle, LA) during the DWH oil spill response. In the present study, effective concentrations of PAHs found to cause significant larval mortalities and growth impairments in the laboratory were substantially higher than the majority of the measured concentrations of PAHs in coastal waters of the northern Gulf of Mexico, and only comparable with some of the measured TPAHs in samples collected in surface waters immediately following the DWH incident.

Results from the current work provide crucial information concerning how particulate oil and its associates could be possibly assimilated by oyster larvae via a dietary route. Like other zooplankton species, oyster larvae may bio-accumulate various PAHs, especially those with high molecular weights (Baumard et al., 1999; Geffard et al., 2002; Lee et al., 2012). Toxic PAHs, including those with carcinogenic potential and so of concern with regard to human consumers (De Flora et al, 1991; Hylland, 2006; Law et al., 1997), could be potentially 
transferred upward through the food chain, and impact the whole ecosystem (Wolfe et al., 1998; Graham et al., 2010; Almeda et al., 2013). Despite the great deal of research conducted on adult bivalves and their ability to bioaccumulate and biotransform organic contaminants, the mechanisms of PAH uptake and potential metabolism by larvae remain little understood. Our findings suggest that relatively low concentrations of PAHs, at levels which could be found in coastal and estuarine areas at the time of the DWH oil spill, can have detrimental consequences on the development and survival of $C$. virginica larvae. It is important to note that the majority of toxicity testing using bivalve larvae focuses only on assessing the acute and short-term effects of oil/PAH, without addressing chronic and long-term effects. A shortterm acute exposure may not reflect the true risk to aquatic organisms under field conditions. For instance, toxic levels of tPAH50 determined in the present study were much lower (e.g. 9 to 36 times lower) than those found in our previous study in which veliger and umbo larvae were acutely exposed for $96 \mathrm{~h}$ (Vignier et al., 2016).

\section{Conclusion}

The present findings show that oil droplets and PAHs can adhere and adsorb to phytoplankton, and that the resulting particles (oil droplets and/or algae) and associated PAHs can become available to oyster larvae and be ingested via a dietary route. Some persistent and toxic PAHs could therefore be transferred to higher trophic levels, and impact the whole ecosystem, and ultimately affect human health. Long-term exposures to chronic levels of tPAH50 (1.6 to $78 \mu \mathrm{g} \mathrm{L}^{-1}$ ) were found to affect larval growth and ultimately survival. To our knowledge, the current study is the first of its kind to challenge Crassostrea virginica larvae to crude oil via a dietary exposure. A potential relationship between PAH bioaccumulation and larval survival and growth must be further examined to better evaluate the short and long-term impacts of crude oil spills on oyster populations.

\section{Acknowledgments}

This work was supported by funds provided as part of the natural resource damage assessment for the Deepwater Horizon oil spill. Data presented here is a subset of a larger toxicological database that is being generated as part of the Deepwater Horizon Natural Resource Damage Assessment. We would like to thank the graduate students and staff at the Vester Marine Field Station. 


\section{Bibliography}

Allan, S. E., Smith, B. W., \& Anderson, K. A. (2012). Impact of the deepwater horizon oil spill on bioavailable polycyclic aromatic hydrocarbons in Gulf of Mexico coastal waters. Environmental science \& technology, 46(4), 2033-2039.

Almeda, R., Wambaugh, Z., Wang, Z., Hyatt, C., Liu, Z., \& Buskey, E. J. (2013). Interactions between zooplankton and crude oil: toxic effects and bioaccumulation of polycyclic aromatic hydrocarbons. PloS one, 8(6), e67212.

Almeda, R., Baca, S., Hyatt, C., \& Buskey, E. J. (2014). Ingestion and sublethal effects of physically and chemically dispersed crude oil on marine planktonic copepods. Ecotoxicology, 1-16.

Anderson, J. W. (1977). Responses to sublethal levels of petroleum hydrocarbons: Are they sensitive indicators and do they correlate with tissue concentration. Fate and Effects of Petroleum Hydrocarbons in Marine Organisms and Ecosystems. D. A. Wolfe, Ed., Pergammon Press, 95-114.

Atlas, R. M. (1995). Bioremediation of petroleum pollutants. International Biodeterioration \& Biodegradation, 35(1), 317-327.

Bahr, L. M., \& Lanier, W. P. (1981). The ecology of intertidal oyster reefs of the South Atlantic coast: a community profile. U.S Fish Wildlife Service Biological Service. FWS/OBS-81/15, 105 p.

Baldwin, B. S., \& Newell, R. I. E. (1991). Omnivorous feeding by planktotrophic larvae of the eastern oyster Crassostrea virginica. Mar. Ecol. Prog. Ser, 78, 285-301.

Baldwin, B. S., \& Newell, R. I. (1995). Relative importance of different size food particles in the natural diet of oyster larvae (Crassostrea virginica). Oceanographic Literature Review, 42(10).

Barron, M. G., Podrabsky, T., Ogle, S., \& Ricker, R. W. (1999). Are aromatic hydrocarbons the primary determinant of petroleum toxicity to aquatic organisms? Aquatic Toxicology, 46(3), 253-268.

Baumard, P., Budzinski, H., Garrigues, P., Narbonne, J. F., Burgeot, T., Michel, X., \& Bellocq, J. (1999). Polycyclic aromatic hydrocarbon (PAH) burden of mussels (Mytilus sp.) in different marine environments in relation with sediment PAH contamination, and bioavailability. Marine Environmental Research, 47(5), 415-439.

Beiras, R. and E. His (1994). Effects of dissolved mercury on embryogenesis, survival, growth and metamorphosis of Crassostrea gigas oyster larvae. Marine Ecology Progress Series 113: 95-103.

Boesch, D (2014) Expert Report prepared on behalf of the United States (TREX-013183). U.S. v. BP Exploration \& Production et al. 12

Boulais, M., Vignier, J., Loh, A. N., Chu, F.L., Lay, C. R., Morris, J. M., Krasnec, M. O., \& Volety, A. (2018 In press). Sublethal effects of oil-contaminated sediment to early life stages of the Eastern oyster, Crassostrea virginica. Environmental Pollution https://doi.org/10.1016/j.envpol.2018.09.017

Calabrese, A., Collier, R. S., Nelson, D. A., \& MacInnes, J. R. (1973). The toxicity of heavy metals to embryos of the American oyster Crassostrea virginica. Marine Biology, 18(3), 162-166.

Chu, F. L. E., Soudant, P., \& Hale, R. C. (2003). Relationship between PCB accumulation and reproductive output in conditioned oysters Crassostrea virginica fed a contaminated algal diet. Aquatic toxicology, 65(3), 293-307. 
Conover, R. J. (1971). Some relations between zooplankton and bunker C oil in Chedabucto Bay following the wreck of the tanker Arrow. Journal of the Fisheries Board of Canada, 28(9), 13271330 .

Croxton, A. N., Wikfors, G. H., \& Schulterbrandt-Gragg, R. D. (2012). Immunomodulation in eastern oysters, Crassostrea virginica, exposed to a PAH-contaminated, microphytobenthic diatom. Aquatic Toxicology, 118, 27-36.

Daling, P. S., Leirvik, F., Almås, I. K., Brandvik, P. J., Hansen, B. H., Lewis, A., \& Reed, M. (2014). Surface weathering and dispersibility of MC252 crude oil. Marine pollution bulletin, 87(1), 300-310.

Davis, H. C., \& Hidu H. (1969). Effects of pesticides on embryonic development of clams and oysters and on survival and growth of the larvae. Fisheries Bulletin, 67(2), 393-404.

De Flora, S., Bagnasco, M., \& Zanacchi, P. (1991). Genotoxic, carcinogenic, and teratogenic hazards in the marine environment, with special reference to the Mediterranean Sea. Mutation Research Reviews in Genetic Toxicology, 258(3), 285-320.

Delvigne, G. A., \& Sweeney, C. E. (1988). Natural dispersion of oil. Oil and Chemical Pollution, 4(4), 281-310.

Drinnan, R. E., \& Stallworthy, W. B. (1979). Oyster Larval Populations and Assessment of Spatfall Bideford River, PEI, 1959. Canadian Fishery and Marine Series Technical Report 793.

Fernandes, M. B., Sicre, M. A., Boireau, A., \& Tronczynski, J. (1997). Poly aromatic hydrocarbon (PAH) distributions in the Seine River and its estuary. Marine Pollution Bulletin, 34(11), 857-867.

Finch, B. E., Stefansson, E. S., Langdon, C. J., Pargee, S. M., Blunt, S. M., Gage, S. J., \& Stubblefield, W. A. (2016). Photo-enhanced toxicity of two weathered Macondo crude oils to early life stages of the eastern oyster (Crassostrea virginica). Marine pollution bulletin, 113(1-2), 316-323.

Finch, B. E., Stefansson, E. S., Langdon, C. J., Pargee, S. M., \& Stubblefield, W. A. (2018). Photoenhanced toxicity of undispersed and dispersed weathered Macondo crude oil to Pacific (Crassostrea gigas) and eastern oyster (Crassostrea virginica) larvae. Marine pollution bulletin, 133, 828-834.

Forth, H. P., Mitchelmore, C. L., Morris, J. M., \& Lipton, J. (2017). Characterization of oil and water accommodated fractions used to conduct aquatic toxicity testing in support of the Deepwater Horizon oil spill natural resource damage assessment. Environmental toxicology and chemistry, 36(6), 14501459 .

Geffard, O., Budzinski, H., \& His, E. (2002). The effects of elutriates from PAH and heavy metal polluted sediments on Crassostrea gigas (Thunberg) embryogenesis, larval growth and bioaccumulation by the larvae of pollutants from sedimentary origin. Ecotoxicology, 11(6), 403-416.

Geffard, O., Geffard, A., His, E., \& Budzinski, H. (2003). Assessment of the bioavailability and toxicity of sediment-associated polycyclic aromatic hydrocarbons and heavy metals applied to Crassostrea gigas embryos and larvae. Marine Pollution Bulletin, 46(4), 481-490.

Graham, W. M., Condon, R. H., Carmichael, R. H., D’Ambra, I., Patterson, H. K., Linn, L. J., \& Hernandez Jr, F. J. (2010). Oil carbon entered the coastal planktonic food web during the Deepwater Horizon oil spill. Environmental Research Letters, 5(4), 045301.

Guillard, R. R. (1975). Culture of phytoplankton for feeding marine invertebrates. In Culture of marine invertebrate animals (pp. 29-60). Springer US. 
Hamilton, M. A., Russo, R. C., \& Thurston, R. V. (1977). Trimmed Spearman-Karber method for estimating median lethal concentrations in toxicity bioassays. Environmental Science \& Technology, 11(7), 714-719.

Hansen, B. H., Altin, D., Olsen, A. J., \& Nordtug, T. (2012). Acute toxicity of naturally and chemically dispersed oil on the filter-feeding copepod Calanus finmarchicus. Ecotoxicology and environmental safety, 86, 38-46.

Hayes, P. F., \& Menzel, R. W. (1981). The reproductive cycle of early setting Crassostrea virginica (Gmelin) in the northern Gulf of Mexico, and its implications for population recruitment. The Biological Bulletin, 160(1), 80-88.

Herbes, S. E. (1977). Partitioning of polycyclic aromatic hydrocarbons between dissolved and particulate phases in natural waters. Water Research, 11(6), 493-496.

Hylland, K. (2006). Polycyclic aromatic hydrocarbon (PAH) ecotoxicology in marine ecosystems. Journal of Toxicology and Environmental Health, Part A,69(1-2), 109-123.

Ingle, R.M. (1951). Spawning and setting of oysters in relation to seasonal environmental changes. Bull. Mar. Sci. Gulf Carib. 1: 111-135

Kayal, S. I., \& Connell, D. W. (1990). Partitioning of unsubstituted polycyclic aromatic hydrocarbons between surface sediments and the water column in the Brisbane River estuary. Marine and Freshwater Research, 41(4), 443-456.

Langdon, C. J., Stefansson, E. S., Pargee, S. M., Blunt, S. M., Gage, S. J., \& Stubblefield, W. A. (2016). Chronic effects of non-weathered and weathered crude oil and dispersant associated with the deepwater horizon incident on development of larvae of the eastern oyster, Crassostrea virginica. Environmental Toxicology and Chemistry. DOI: 10.1002/etc.3352

Laramore, S., Krebs, W., \& Garr, A. (2014). Effects of Macondo Canyon 252 oil (naturally and chemically dispersed) on larval Crassostrea virginica (Gmelin, 1791). Journal of Shellfish Research, 33(3), 709-718.

Law, R. J., Dawes, V. J., Woodhead, R. J., \& Matthiessen, P. (1997). Polycyclic aromatic hydrocarbons (PAH) in seawater around England and Wales. Marine pollution bulletin, 34(5), 306322.

Lee, R. F., Gardner, W. S., Anderson, J. W., Blaylock, J. W., \& Barwell-Clarke, J. (1978). Fate of polycyclic aromatic hydrocarbons in controlled ecosystem enclosures. Environmental Science \& Technology, 12(7), 832-838.

Lee, R. F., Köster, M., \& Paffenhöfer, G. A. (2012). Ingestion and defecation of dispersed oil droplets by pelagic tunicates. Journal of plankton research,34(12), 1058-1063.

Lewis, A., \& Daling, P. (2001). Oil spill dispersants. Guidelines on the Planning and Effective Use of Oil Spill Dispersants to Minimise the Effects of Oil Spills. Consultant AMOS Report. SINTEF,Trondheim, 1-113.

Li, M. and Garrett, C. (1998). The relationship between oil droplet size and upper ocean turbulence. Marine Pollution Bulletin 36(12): 961-970.

Lichtenthaler, R. G., \& Daling, P. S. (1985, February). Aerial application of dispersants-comparison of slick behavior of chemically treated versus non-treated slicks. In: Proceedings 1985 International Oil Spill Conference : American Petroleum Institute, Washington, DC. 471-478

Losso, C., Novelli, A. A., Picone, M., Marchetto, D., Pantani, C., Ghetti, P. F., \& Ghirardini, A. V. (2007). Potential role of sulfide and ammonia as confounding factors in elutriate toxicity bioassays 
with early life stages of sea urchins and bivalves. Ecotoxicology and environmental safety, 66(2), 252257.

Lyman, W. J. (1995). Transport and transformation processes. In: Rand, GM, editor. Fundamentals of Aquatic Toxicology: Effects, Environmental Fate, and Risk Assessment. $2^{\text {nd }}$ Edition. Taylor and Francis, Washington, DC.

Meador, J. P., Stein, J. E., Reichert, W. L., \& Varanasi, U. (1995). Bioaccumulation of polycyclic aromatic hydrocarbons by marine organisms. In Reviews of environmental contamination and toxicology (pp. 79-165). Springer, New York, NY.

Mukherjee, B., \& Wrenn, B. A. (2009). Influence of dynamic mixing energy on dispersant performance: role of mixing systems. Environmental Engineering Science, 26(12), 1725-1737.

Neff, J. M. (1979). Polycyclic aromatic hydrocarbons in the aquatic environment: sources, fates and biological effects. London, Applied Sciences Publishers LTD.

Neff, J. M., \& Stubblefield, W. A. (1995). Chemical and toxicological evaluation of water quality following the Exxon Valdez oil spill. ASTM Special Technical Publication, (1219), 141-177.

Nixon, Z., Zengel, S., \& Michel, J. NOAA Technical Report: Categorization of Shoreline Oiling from the Deepwater Horizon Oil Spill. (September 1, 2015) https://pub-dwhdatadiver.orr.noaa.gov/dwh-ardocuments/901/DWH-AR0270684.pdf

Okay, O. S., Donkin, P., Peters, L. D., \& Livingstone, D. R. (2000). The role of algae (Isochrysis galbana) enrichment on the bioaccumulation of benzo [a] pyrene and its effects on the blue mussel Mytilus edulis. Environmental Pollution, 110(1), 103-113.

Ponis E., Probert I., Véron B., Mathieu M., Robert R., 2006. New microalgae for the Pacific oyster Crassostrea gigas larvae. Aquaculture 23 : 618-627.

Porte, C., \& Albaiges, J. (1994). Bioaccumulation patterns of hydrocarbons and polychlorinated biphenyls in bivalves, crustaceans, and fishes. Archives of Environmental Contamination and Toxicology, 26(3), 273-281.

Ritz, C. (2010). Toward a unified approach to dose-response modeling in ecotoxicology. Environmental Toxicology and Chemistry 29(1):220-229.

Ritz, C. and Streibig, J. C. (2005). Bioassay analysis using R. Journal of Statistical Software 12(5).

Robert R., Chrétiennot-Dinet M.J., Kaas R., Martin-Jézéquel V., Moal J., Le Coz J.R., Nicolas J.L., Bernard E., Connan J.P., Le Dean L., Gourrierec G. Leroy B., Quéré C., (2004). Amélioration des productions phytoplanctoniques en écloserie de mollusques : caractérisation des microalgues fourrage, RI DRV RA-2004-05, 149p.

Rubinstein, N. I., Gilliam, W. T., \& Gregory, N. R. (1984). Dietary accumulation of PCBs from a contaminated sediment source by a demersal fish (Leiostomus xanthurus). Aquatic toxicology, 5(4), 331-342.

Sandoval, K., Ding, Y., \& Gardinali, P. (2017). Characterization and environmental relevance of oil water preparations of fresh and weathered MC-252 Macondo oils used in toxicology testing. Science of The Total Environment, 576, 118-128.

Spacie, A., McCarty, L. S., \& Rand, G. M. (1995). Bioaccumulation and bioavailability in multiphase systems. In: Rand, GM, editor. Fundamentals of Aquatic Toxicology: Effects, Environmental Fate, and Risk Assessment. $2^{\text {nd }}$ Edition. Taylor \& Francis, Washington, DC. 
Stefansson, E. S., Langdon, C. J., Pargee, S. M., Blunt, S. M., Gage, S. J., \& Stubblefield, W. A. (2016). Acute effects of non- weathered and weathered crude oil and dispersant associated with the Deepwater Horizon incident on the development of marine bivalve and echinoderm larvae. Environmental toxicology and chemistry, 35(8), 2016-2028.

U.S. District Court. (2014). In re: Oil Spill by the Oil Rig "Deepwater Horizon" in the Gulf of Mexico, on April 20, 2010, No. MDL 2179, Section 7 (Revised September 9, 2014) ("Findings of Fact and Conclusions of Law: Phase One Trial"), Figure 1. United States District Court for the Eastern District of Louisiana.

U.S. District Court. (2015). In re: Oil Spill by the Oil Rig "Deepwater Horizon" in the Gulf of Mexico, on April 20, 2010, No. MDL 2179, 2015 WL 225421 (La. E.D. Jan. 15, 2015) ("Findings of Fact and Conclusions of Law: Phase Two Trial"). United States District Court for the Eastern District of Louisiana.

Utting, S. D. and Millican, P. F. (1997). Techniques for the hatchery conditioning of bivalve broodstocks and the subsequent effect on egg quality and larval viability. Aquaculture 155(1): 45-54.

Vignier, J., Donaghy, L., Soudant, P., Chu, F. L. E., Morris, J. M., Carney, M. W., Lay, C. R., Krasnec, M. O., Robert, R. \& Volety, A. K. (2015). Impacts of Deepwater Horizon oil and associated dispersant on early development of the Eastern oyster Crassostrea virginica. Marine pollution bulletin, 100(1), 426-437.

Vignier, J., Soudant, P., Chu, F. L. E., Morris, J. M., Carney, M. W., Lay, C. R., Krasnec, M. O., Robert, R. \& Volety, A. K. (2016). Lethal and sub-lethal effects of Deepwater Horizon slick oil and dispersant on oyster (Crassostrea virginica) larvae. Marine environmental research, 120, 20-31.

Vignier, J., Volety, A. K., Rolton, A., Le Goïc, N., Chu, F. L., Robert, R., \& Soudant, P. (2017). Sensitivity of eastern oyster (Crassostrea virginica) spermatozoa and oocytes to dispersed oil: Cellular responses and impacts on fertilization and embryogenesis. Environmental pollution, 225, 270-282.

Volety, A., Boulais, M., Donaghy, L., Vignier, J., Loh, A. N., \& Soudant, P. (2016). Application of flow cytometry to assess Deepwater Horizon oil toxicity on the Eastern Oyster Crassostrea virginica Spermatozoa. Journal of Shellfish Research, 35(1), 91-99.

Wade, T. L., Sweet, S. T., Sericano, J. L., Guinasso, N. L., Diercks, A. R. R., Highsmith, R. C., \& Joye, S. B. (2011). Analyses of water samples from the Deepwater Horizon oil spill: Documentation of the subsurface plume. Monitoring and Modeling the deepwater horizon oil spill: a record-breaking enterprise, 77-82.

Walsh, G. E. (1978). Toxic effects of pollutants on Plankton. Principles of Ecotoxicology. John Wiley \& Sons, Inc., New York, 257-274.

Widdows, J., Bakke, T., Bayne, B. L., Donkin, P., Livingstone, D. R., Lowe, D. M., \& Moore, S. L. (1982). Responses of Mytilus edulis on exposure to the water-accommodated fraction of North Sea oil. Marine Biology, 67(1), 15-31.

Wolfe, M. F., Schlosser, J. A., Schwartz, G. J. B., Singaram, S., Mielbrecht, E. E., Tjeerdema, R. S., \& Sowby, M. L. (1998). Influence of dispersants on the bioavailability and trophic transfer of petroleum hydrocarbons to primary levels of a marine food chain. Aquatic Toxicology, 42(3), 211227.

Wolfe, M. F., Schwartz, G. J. B., Singaram, S., Mielbrecht, E. E., Tjeerdema, R. S., \& Sowby, M. L. (2000). Influence of dispersants on the bioavailability and trophic transfer of phenanthrene to algae and rotifers. Aquatic toxicology, 48(1), 13-24. 


\section{Appendix: Supplementary data}

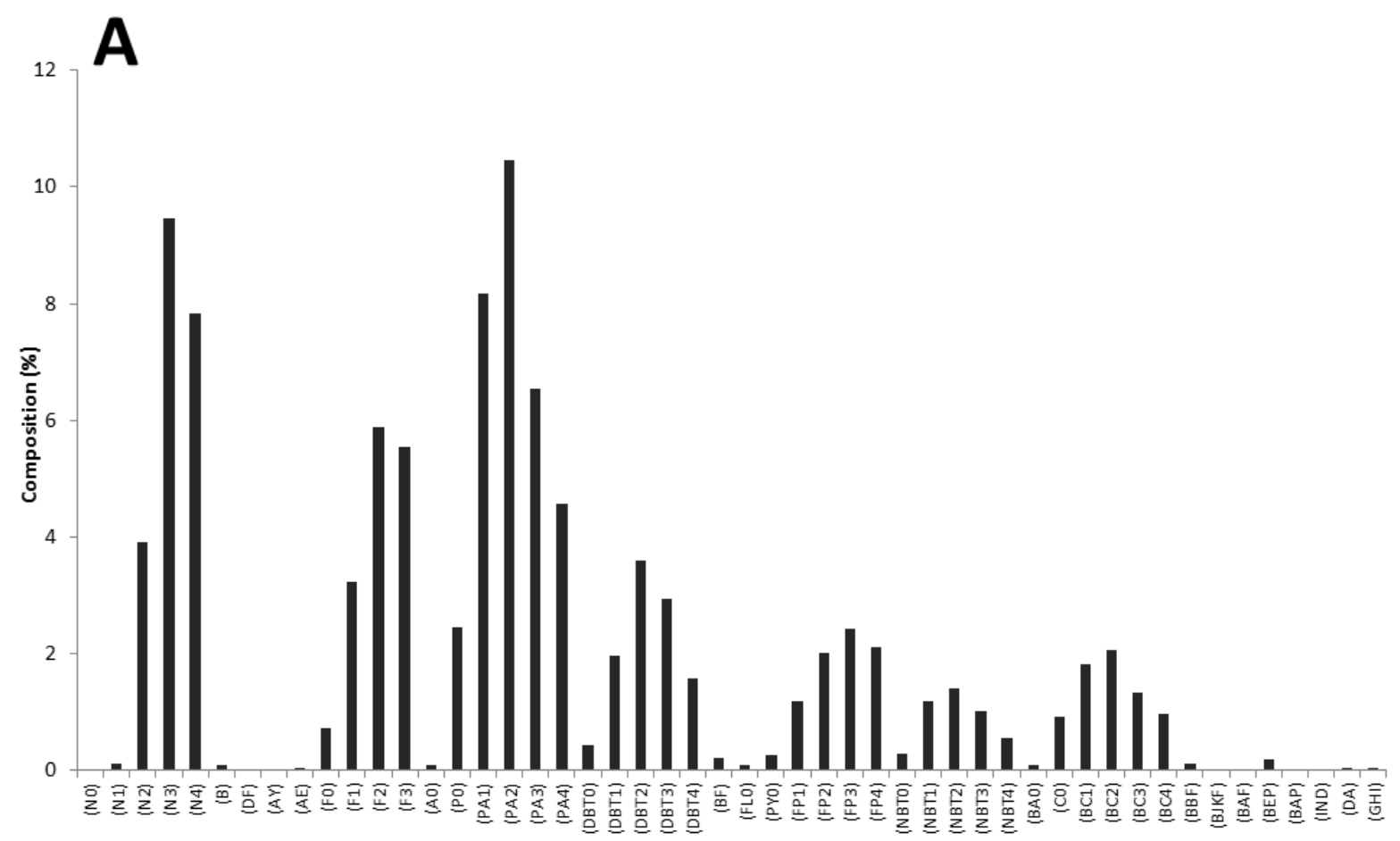




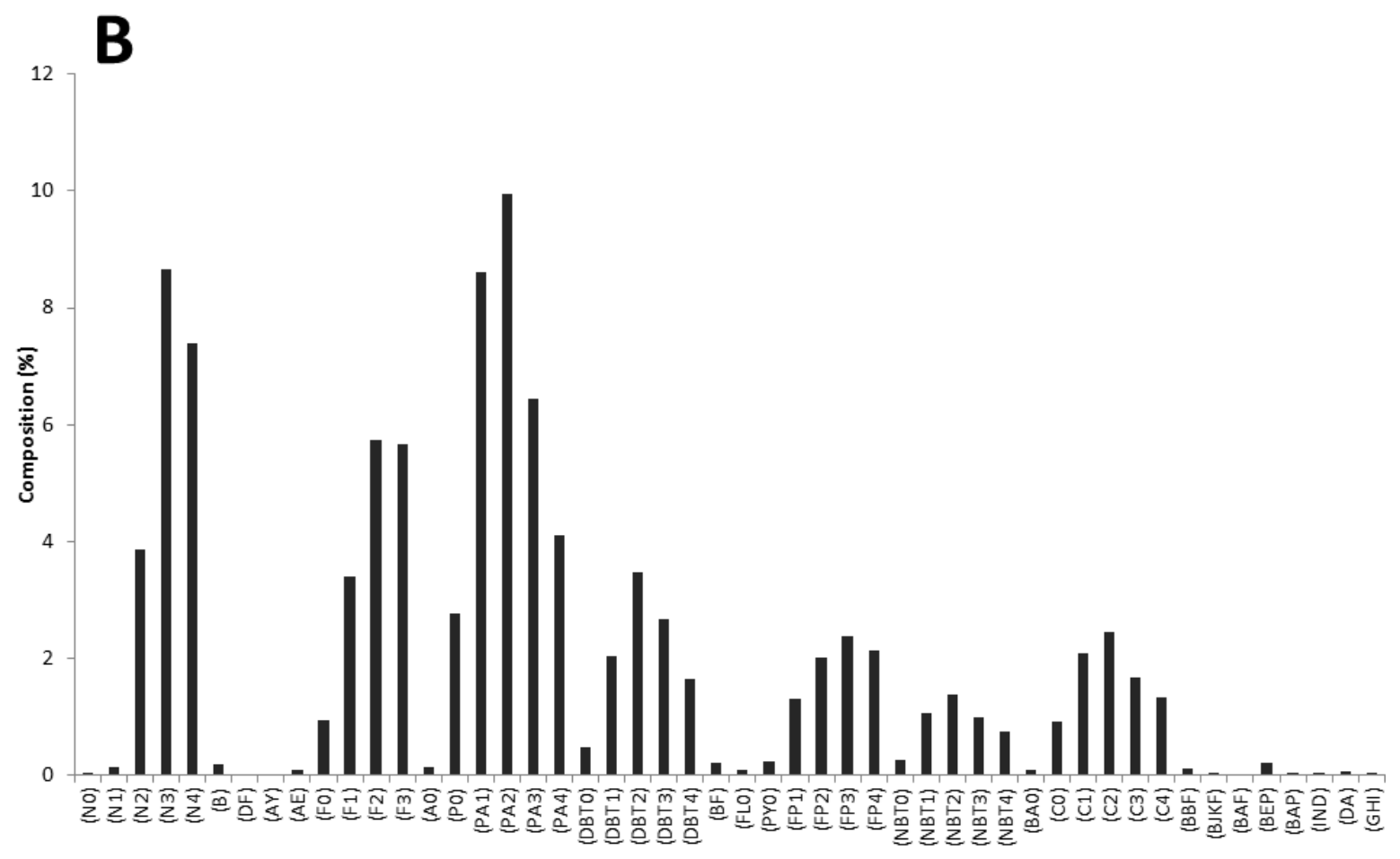

Supplementary file 1: Profile of the 50 PAHs contained in the crude oil "Slick A" (A) and the stock solution of HEWAF (B), expressed as \% composition, quantified by GC/MS-SIM. Content of total PAHs ( $\mathrm{n}=50)$ in crude oil corresponds to $0.31 \%$ of the mass. HEWAF stock solution corresponds to nominal oil load of $2 \mathrm{~g}^{\circ}$ il $\mathrm{L}^{-1}$. Napthalene; B: Biphenyl; AY: Acenaphtylene; AE: Acenaphtene; F0-3: Fluorene; A0: Anthracene; PA0-4: Phenanthrene; DBT0-4: Dibenzothiophene; BF:Benzo(b)fluorine; FLO: Fluoranthene; PY0: Pyrene; FP1-4: Fluoranthene/Pyrene; NBT0-4: Naphtobenzothiophene; BAO: Benz(a)anthracene; C0-4: Chrysene; BBF: Benzo(b)fluoranthene; BJKF: Benzo(j+k)fluoranthene; BAF: Benzo(a)fluoranthene; BEP: Benzo(e)pyrene; BAP: Benzo(a)pyrene; IND: Indeno(1,2,3)pyrene; DA: Dibenz(a,h)anthracene; GHI: Benzo(g,h,i)perylene. Parent compound is indicated by a 0 (e.g. N0), while numbers of additional carbons for alkylated homologs are indicated as N1, N2, etc. Target method detection limit range: 1 - $5 \mathrm{ng} / \mathrm{L}$.

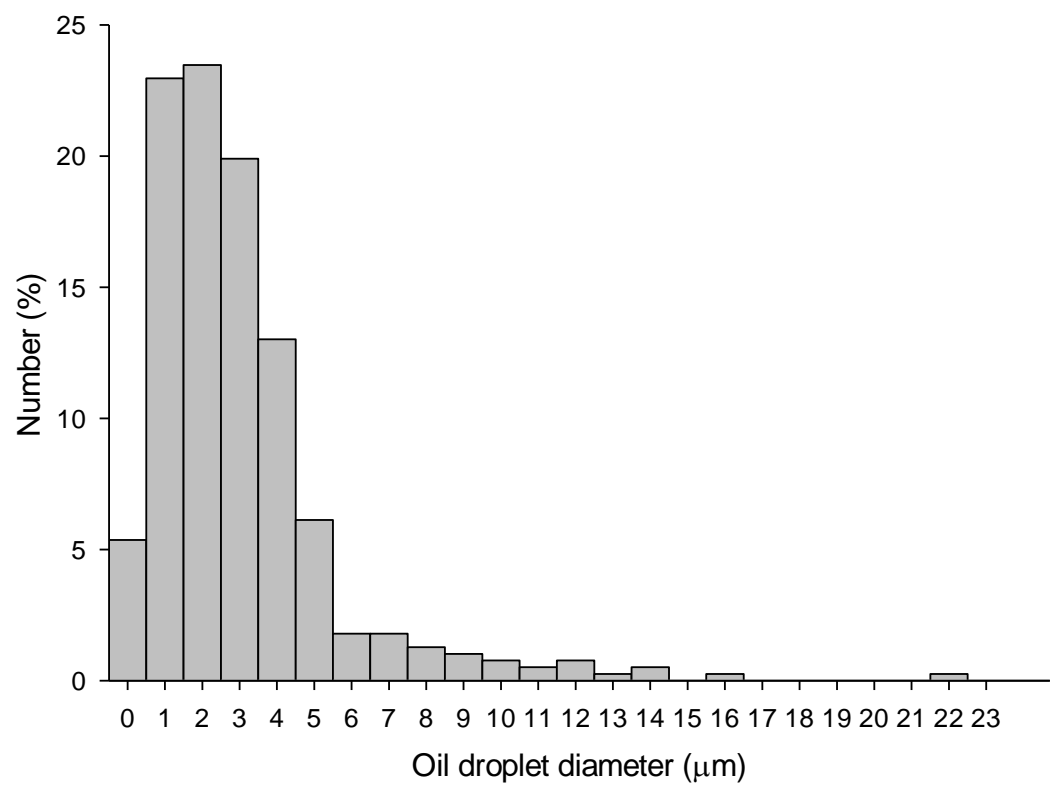

Supplementary file 2: Size distribution (in \%) of oil droplets, expressed in $\mu \mathrm{m}$, observed in unfiltered HEWAF stock ( $2 \mathrm{~g} \mathrm{~L}^{-1}$ oil loading rate). 